\title{
Effect of Canola oil Supplementation Level on Total Tract Digestion, Ruminal Fermentation and Methane Emissions of Cows Grazing Brachiaria sp Complemented with Fixed Amount of Concentrate
}

\section{Jonathan Noe Avilés-Nieto}

Universidad Nacional Autonoma de Mexico Facultad de Medicina Veterinaria y Zootecnia

Claudia Cecilia Márquez-Mota

Universidad Nacional Autonoma de Mexico Facultad de Medicina Veterinaria y Zootecnia Juan Heberth Hernández-Medrano

University of Nottingham School of Medicine

Jacinto Efren Ramírez-Bribiesca

Colegio de Postgraduados

\section{Epigmenio Castillo-Gallegos}

Universidad Nacional Autonoma de Mexico Facultad de Medicina Veterinaria y Zootecnia

\section{Alejandro Plascencia}

Universidad Autonoma de Occidente

Francisco Alejandro Castrejón-Pineda

Universidad Nacional Autonoma de Mexico Facultad de Medicina Veterinaria y Zootecnia

Luis Corona ( $\nabla$ gochi@unam.mx )

Universidad Nacional Autonoma de Mexico Facultad de Medicina Veterinaria y Zootecnia https://orcid.org/0000-0002-6640-7626

\section{Research Article}

Keywords: Methane, Canola oil, Cattle, Grazing, Digestion

Posted Date: February 3rd, 2022

DOI: https://doi.org/10.21203/rs.3.rs-1290372/v1

License: (9) (1) This work is licensed under a Creative Commons Attribution 4.0 International License.

Read Full License 


\section{Abstract}

Four rumen-cannulated cows (Bos taurus $\times$ Bos indicus, $631 \pm 88 \mathrm{BW}$ ) were assigned in a $4 \times 4$ Latin Square design to test the effects of different canola oil inclusion levels (CO; 0.0, 0.40, 0.80 and $1.2 \mathrm{~g} / \mathrm{kg}$ shrunk body weight, $\mathrm{SBW}=\mathrm{BW} \times 0.96)$ on the reduction of $\mathrm{CH}_{4}$ emissions and the energy value of the diet based on Brachiaria sp. under rotational grazing supplemented with a fixed amount of concentrate. The $\mathrm{CH}_{4}$ emission was analysed by an infrared analyser. Grass consumption and faecal production were estimated using $\mathrm{Cr}_{2} \mathrm{O}_{3}$ as external marker. The $\mathrm{CO}$ supplementation increased (linear effect, $\left.\mathrm{P}<0.05\right) \mathrm{DM}$ (16.6\%), organic matter (OM, 18.0\%) and gross energy intakes $(26.3 \%)$ and decreased the total digestibility of neutral detergent fibre (NDF) by $26 \%$ (linear effect, $\mathrm{P}<0.05$ ); also increased digestible energy value (Mcal $/ \mathrm{kg})$ by $7.1 \%$. In the rumen, the maximum oil inclusion level decreased the total protozoa population by $89 \%$, the acetate: propionate ratio by $25 \%$ and the enteric methane production by $18.9 \%$, all without negatively affecting any of the other variables of fermentation and digestion evaluated. It is concluded that canola oil at supplementation levels of up to $1.2 \mathrm{~g} \mathrm{CO} / \mathrm{kg} \mathrm{SBW} \mathrm{(5.3 \%} \mathrm{of} \mathrm{the} \mathrm{total} \mathrm{diet)}$ for cows grazing tropical forages supplemented with concentrates increases the total and energy consumption and the efficiency of ruminal fermentation, thereby reducing the emission of enteric methane by up to $18.9 \%$.

\section{Introduction}

Cattle are among the major contributors to greenhouse gas (GHG) emissions, mainly methane $\left(\mathrm{CH}_{4}\right)$ from enteric fermentation and from extensive grazing production systems. The emission of methane represents a significant energy loss, ranging from 2 to $12 \%$ of energy intake (Audsley and Wilkinson, 2014; Beauchemin, 2015; Hristov et al., 2015). Therefore, the challenge is to develop diets and strategies for $\mathrm{CH}_{4}$ emission reduction by optimising diet energy use, which should improve productive performance and reduce the impact on global warming (McGeough et al., 2010, Wu et al., 2016).

Previous reports have pointed out the addition of lipids to diets as a strategy to reduce $\mathrm{CH}_{4}$ emissions in ruminants (Grainger and Beauchemin, 2011; Hristov et al., 2013; Knapp et al., 2014; Martin et al., 2016). Unsaturated fatty acids (UFA) reduce $\mathrm{CH}_{4}$ by increasing propionic acid production, inhibiting protozoa survival and UFA hydrogenation (Bonilla and Lemus et al., 2012, Mata e Silva et al., 2017). For this purpose, long-chain (C18) UFAs, i.e., vegetable and fish oils, are more effective; the most abundant ones are oleic (C18:1) and linoleic (C18:2) FAs, and their proportions change according to the oil source (Orsavova et al., 2015). In-vitro studies have shown that the addition of UFAs to the ruminal inoculum can decrease $\mathrm{CH}_{4}$ production (Castro-Montoya et al., 2015; Wu et al., 2016). However, oil supplementation needs to be performed carefully, especially in grazing cattle, because of the negative effects on the ruminal degradation of NDF (Jenkins and Palmquist, 1984) and the low intestinal digestibility (as well as the usable energy value of lipids) when supplemented at high levels (Zinn and Jorquera, 2007). PiñaresPatiño et al. (2016) added canola oil directly to Lolium perenne meadow grass ( $733 \mathrm{~g}$ of oil/animal/day), which resulted in a lower ruminal acetate/propionate ratio and an $11 \%$ decrease in $\mathrm{CH}_{4}$ compared to non- 
supplemented animals. Angus heifers on a barley silage diet (75\% of diet DM; Beauchemin and McGinn, 2006), supplemented with $4.6 \%$ canola oil (CO; equivalent to $1.2 \mathrm{~g}$ oil $/ \mathrm{kg} \mathrm{SBW}$ ), showed a $32 \%$ decrease in methane emissions. However, this reduction was due to a decrease in feed intake and total tract DM digestibility as a direct consequence of NDF digestion decrease.

To date, the effects of oil supplementation have mostly been reported for temperate conditions, whereas reports for tropical grazing conditions are lacking. Under tropical conditions, the diet is based on grasses with lower NDF digestibility, nitrogen $(\mathrm{N})$ content and available energy; these characteristics decrease $\mathrm{N}$ and carbon retention efficiency, favouring an increase in enteric $\mathrm{CH}_{4}$ production. Therefore, a feasible GHG mitigation strategy is to use concentrates containing adequate amounts of vegetable oils to increase energy intake, with a minimum effect on NDF forage digestibility, to significantly decrease enteric $\mathrm{CH}_{4}$ emissions. Mate and Silva et al. (2017) reported a 23\% reduction in $\mathrm{CH}_{4}$ emissions in dairy cows (Holstein $\times$ Gyr) grazing Urochloa sp. supplemented with $2.86 \mathrm{~kg} /$ day concentrate containing 13.4\% sunflower oil ( $0.73 \mathrm{~g}$ of oil $/ \mathrm{kg}$ of live weight). Although in their study, milk production was evaluated, the variables of ruminal digestion and fermentation were not considered; however, a decrease in $\mathrm{CH}_{4}$ reduces the loss of gross energy intake by the animal from 2 to $12 \%$ (Johnson and Johnson, 1995). Furthermore, in beef cattle, a maximum lipid intake of $0.96 \mathrm{~g} / \mathrm{kg} \mathrm{LW}$ has been determined for optimal FA digestibility, which represents an adequate fat usable energy value (Zinn \& Jorquera, 2007). Therefore, the level used by Mata and Silva (2017) was $24 \%$ lower than the theoretical optimal inclusion level. Consequently, it is necessary to determine the optimum level of vegetable oil inclusion to reduce methane emissions without negatively affecting DM intake and dietary energy use in cattle grazing under tropical conditions. In this context, the objective of this study was to evaluate the effect of canola oil inclusion level on nutrient digestibility, ruminal fermentation and enteric $\mathrm{CH}_{4}$ emissions in grazing cattle under tropical conditions and complemented with a fixed amount of concentrate.

\section{Materials And Methods}

\section{Location}

The study was carried out at the Center for Teaching, Research and Extension in Tropical Livestock (CEIEGT, FMVZ-UNAM), located in Tlapacoyan, Veracruz, Mexico $\left(20^{\circ} 03^{\prime} \mathrm{N}\right.$ and $\left.93^{\circ} 03^{\prime} \mathrm{W}\right)$. The climate is hot and humid, Af $(\mathrm{m}) \mathrm{w}$ "(e) (García, 2004), with an average daily temperature of $23.9 \pm 0.5^{\circ} \mathrm{C}$ and an average annual rainfall of $1,931 \pm 334 \mathrm{~mm}$.

The study used four non-pregnant rumen-cannulated adult cross-bred (Bos taurus $\times$ B. indicus) cows with an average BW of $631 \pm 88 \mathrm{~kg}$. Cows were weighed daily at $1100 \mathrm{~h}$ for 3 consecutive days, and body weight adjusted to the Shrunk Body Weight (SBW) by multiplying body weight with a correction factor of 0.96 to account for gut fill, according to the National Academies of Sciences, Engineering, and Medicine (NASEM; 2016).

\section{Animals, feeding and experimental design}


The cows were subjected to a $4 \times 4$ Latin square design to test four levels of canola oil (CO) inclusion: $0.0,0.40,0.80$ and $1.20 \mathrm{~g} \mathrm{CO} / \mathrm{kg}$ SBW. Cows were housed in 1 hectare of a Brachiaria spp. grazing paddock, which was divided into four pasture sections of $50 \times 50 \mathrm{~m}$. Feeding was based on a rotational grazing system of 7 days per paddock, with a recovery period of 21 days, ensuring an average height of the pasture of $40 \mathrm{~cm}$ before grazing and $10 \mathrm{~cm}$ of residual. To achieve the level of intake, the required CO was mixed into pelletised commercial concentrate to obtain final concentrations of $0,40,80$ and $120 \mathrm{~g}$ $\mathrm{CO} / \mathrm{kg}$ concentrate. This combination was offered individually at $6.3 \mathrm{~kg} /$ animal so that the total daily intake of CO was $0,250,502$ and $752 \mathrm{~g}$, corresponding to $0.0,0.40,0.80$ and $1.20 \mathrm{~g} \mathrm{CO} / \mathrm{kg} \mathrm{SBW}$, respectively (Zinn and Jorquera 2003; Bayat et al., 2018). The concentrate was offered in equal amounts $(3.51 \mathrm{~kg})$ at 0600 and $1500 \mathrm{~h}$. Residual concentrate was introduced directly to the rumen via the ruminal cannula to ensure correct oil consumption.

\section{Sampling and measurements}

The trial consisted of four periods of 19 days each, corresponding to 13 days of gradual adaptation to the treatment and 6 sampling days. Dry matter intake (DMI) was estimated using the chromium oxide technique $\left(\mathrm{Cr}_{2} \mathrm{O}_{3}\right.$; Schneider and Flatt, 1975). The animals received $10 \mathrm{~g}$ of $\mathrm{Cr}_{2} \mathrm{O}_{3}$ absorbed into cellulose paper envelopes and daily placed directly into the rumen via the cannula, from day 8 to 17 of each period at the same time $(1530 \mathrm{~h})$. Individual faecal samples $(200 \mathrm{~g})$ were collected directly from the rectum every 8 hours during the last 4 days of each treatment period, starting at $0000 \mathrm{~h}$ on day 1, 0200 on day 2, 0400 on day 3 and 0600 on day 4 . Samples were kept refrigerated $\left(1^{\circ} \mathrm{C}\right)$ and homogenised at the end of each period to generate a composite sample, which was frozen $\left(-18^{\circ} \mathrm{C}\right)$ until analysis.

Ruminal fluid samples were collected every 4 hours on days 18 and 19 of each period, starting at 0300h; samples were filtered through eight gauze layers, and their $\mathrm{pH}$ values were measured using a portable potentiometer (Oakton, pHTestrs ${ }^{\circledR}$ ). For protozoa estimation, 5 -mL filtered ruminal fluid samples were collected, and $5 \mathrm{~mL}$ iodine solution was added $(5 \mathrm{~mL} ; 1.5 \mathrm{~g}$ potassium iodine and $0.5 \mathrm{~g}$ iodine resublimated volumetric $100 \mathrm{~mL})$. Samples were kept under refrigeration $\left(1^{\circ} \mathrm{C}\right)$ until analysis. The filtered ruminal fluid $(40 \mathrm{~mL})$ corresponding to $4 \mathrm{~h}$ post-feeding ( $1900 \mathrm{~h}$ concentrate and $0300 \mathrm{~h}$ forage) was preserved with $10 \mathrm{~mL}$ metaphosphoric acid at $25 \%(\mathrm{v} / \mathrm{v})$ and frozen $\left(-18^{\circ} \mathrm{C}\right)$ for the estimation of ammonia nitrogen $\left(\mathrm{NH}_{3}-\mathrm{N}\right)$ and volatile fatty acids (VFA).

To evaluate $\mathrm{CH}_{4}$ emissions, animals were moved to individual stalls with a closed trough, and methane was estimated using an infrared methane analyser (Guardian Plus; Edinburg Instruments Ltd., Livingston, UK) with the "sniffer method", as reported by Garnsworthy et al. (2012). The $\mathrm{CH}_{4}$ emissions were estimated during the concentrate feeding time at 0600 and $1500 \mathrm{~h}$ for a period of $\sim 30 \mathrm{~min}$.

The energy loss due to $\mathrm{CH}_{4}$ emission $\left(Y_{m}\right)$ was estimated with the formula proposed by Sauvant and Giger-Reverdin (2009):

$\mathrm{Y}_{\mathrm{m}}=10.8-2.99 \times \mathrm{LI}+0.40 \times \mathrm{LI} 2+7.23 \times \mathrm{CPr}-8.71 \times \mathrm{CPr} 2-0.98 \times \mathrm{CPr} \times \mathrm{LI}$, 
where $\mathbf{Y}_{\mathrm{m}}$ represents $\mathrm{CH}_{4}$ energy as a percentage of gross energy; $\mathrm{LI}$ indicates intake level as a percentage of body weight; $\mathrm{CPr}$ is the proportion of concentrate in the diet.

Using the methodology of the Intergovernmental Panel on Climate Change (IPCC, 2006), $\mathrm{CH}_{4}$ emissions were estimated using the GE and CMS values obtained during the experiment, according to the following equation:

$$
E F=\left[\frac{G E \cdot\left(\frac{Y m}{100}\right) \cdot 365}{55.65}\right],
$$

where $\mathbf{E F}=$ emission factor, $\mathrm{kg} \mathrm{CH}_{4}$ head $^{-1} \mathrm{yr}^{-1} ; \mathbf{G E}=$ gross energy intake, $\mathrm{MJ}$ head $^{-1}$ day $^{-1} ; \mathbf{Y}_{\mathrm{m}}=$ methane conversion factor, percentage of feed gross energy converted to methane. The constant value 55.65 $\left(\mathrm{MJ} / \mathrm{kg} \mathrm{CH}{ }_{4}\right)$ was used as the energy content of methane.

Representative samples of concentrate and forage for the grazing paddock were taken. Faecal, forage and concentrate samples were dried at $60^{\circ} \mathrm{C}$ for $72 \mathrm{~h}$, ground and sieved $(1 \mathrm{~mm})$ for further analysis.

\section{Sample analysis and calculations}

Samples were subjected to all or part of the following analyses: dry matter (DM , oven-drying until no further weight loss, method 934.01; AOAC, 2015), crude protein (CP, method 2001.11; AOAC, 2015), ash (method 942.05; AOAC, 2015) ), neutral detergent fibre (NDF) and acid detergent fibre (ADF), as described by Van Soest et al. (1991), using alpha-amylase without correction for ash and an ANKOM 2000 analyser, gross energy (GE), using the calorimetric pump approach (Parr, 6400; Illinois, USA). Chromium oxide $\left(\mathrm{Cr}_{2} \mathrm{O}_{3}\right)$ in faecal samples was determined using atomic absorption spectrometry following Williams et al. (1962). Medium- and long-chain FA determination was performed by gas chromatography (Perkin Elmer, model AutoSystem XL) using a CP-7420 Select column $100 \mathrm{~m} \times 0.2 \mathrm{~mm} \times 0.25$ um FAME capillary column (Agilent Technologies). To carry out the methylation of the FA, the methodology AOAC (2019) Official Method 969.33 (2005) was used. For the calculations, we used the AOAC (2019) Official Method 963.22. The chromatograph conditions were as follows: flow rate, $1.5 \mathrm{~mL} / \mathrm{min}$; temperature, $80^{\circ} \mathrm{C}$; injector temperature, $220^{\circ} \mathrm{C}$; detector temperature (FID): $275-280^{\circ} \mathrm{C}$; Conditions: $80^{\circ} \mathrm{C}(1 \mathrm{~min}), 20^{\circ} \mathrm{C} / \mathrm{min}, 160^{\circ} \mathrm{C}$, $1^{\circ} \mathrm{C} / \mathrm{min}, 198^{\circ} \mathrm{C}, 5^{\circ} \mathrm{C} / \mathrm{min} 250^{\circ} \mathrm{C}(15 \mathrm{~min})$. Chromatographic analysis was performed with the Supelco TM 37 Component FAME MIX standard, catalogue number 47885-U.

Protozoa were microscopically counted (US Micro 2, US Micro products, Austin, TX, USA) using a haemocytometer (Neubauer improved, Marienfeld, Germany) to estimate the number per $\mathrm{mL}$. Six observations were made per sample/hour/animal/treatment/period, with the total number and genre recorded (Holotrichidae and Entodinidae). Ammonia nitrogen $\left(\mathrm{NH}_{3}-\mathrm{N}\right)$ was estimated using the Conway and O'Malley (1942) technique, and the VFA profile was measured by gas chromatography (Perkin Elmer, AutoSystem XL model). 
Faecal excretion of DM and individual nutrients were calculated based on marker ratios using $\mathrm{Cr}_{2} \mathrm{O}_{3}$.

\section{Statistical analysis}

Data were analysed as a $4 \times 4$ Latin Square design using the MIXED procedure of SAS 9.1 (Statistical Analysis System, Inc., Cary, NC, USA), according to the following model:

$Y_{i j}=\mu+H_{i}+C_{j}+T_{k}+\varepsilon_{i j}$

where $Y_{i j k}=$ variable response, $\mu$ = overall average, $H_{i}=$ effect of the $i$-th animal (row), $C_{j}=$ effect of the $j$-th period (column), $T_{k}=$ effect of the $k$-th treatment and $\varepsilon_{i j k}=$ experimental error. The effects of treatment means were analysed using polynomial orthogonal for linear and quadratic components of the level of CO (Cochran and Cox, 1992). For ruminal fermentation (VFAs, protozoa number estimation and methane emission), sampling period/time was included as a repeated measure; differences with $P$ values $\leq 0.05$ were considered statistically significant.

\section{Results}

The fatty acid profile and the chemical compositions of $\mathrm{CO}$, concentrate and grass offered are shown in Table 1. The lipid concentration was 2.26, 3.00 and $99 \%$ for the Brachiaria spp. grass, the commercial concentrate and the canola oil, respectively. 
Table 1

Chemical compositions and fatty acid profile of the ingredients.

\begin{tabular}{|llll|}
\hline Items & Canola oil & Brachiaria sp. & Concentrate \\
\hline Crude Protein & ND & 6.4 & 17.5 \\
\hline Ashes & ND & 11.1 & 20.7 \\
\hline Neutral Detergent Fiber & ND & 66.6 & 41.8 \\
\hline Acid Detergent Fiber & ND & 41.4 & 14.6 \\
\hline Ethereum Extract & 99.0 & 2.26 & 3.0 \\
\hline Gross Energy & 9.5 & 3.7 & 3.7 \\
\hline Fatty acids (\%) & & & \\
\hline C6: 0, Caproic & 0.13 & 0.00 & 0.00 \\
\hline C8: 0, Caprylic & 0.12 & 0.00 & 0.00 \\
\hline C12: 0, Lauric & 0.14 & 0.00 & 5.77 \\
\hline C14: 0, Myristic & 0.37 & 0.00 & 2.61 \\
\hline C16: 0, Palmitic & 10.6 & 41.78 & 26.5 \\
\hline C16: 1, Palmitoleic & 0.18 & 0.00 & 0.00 \\
\hline C17: 0, Margaric & 0.12 & 0.00 & 0.00 \\
\hline C18: 0, Stearic & 0.02 & 0.00 & 0.00 \\
\hline C18: 1, Oleic & 0.84 & 0.00 & 0.00 \\
\hline C18: 2, Linoleic, & 0.99 & 3.42 & 0.00 \\
\hline C18: 3, a-Linolenic acid & 70.32 & 39.2 & 4.00 .84 \\
\hline C20: 0, Arachidonic, & 5.09 & 8.28 & 15.42 \\
\hline C20: 1, Eicosenoic, & 0.14 & 0.00 & 0.00 \\
\hline C21: 0, Heneicosenoic, & 0.00 & 0.00 \\
\hline C22: 1, Behenic and C22: Erucic & 0.70 & 0.00 & 0.00 \\
\hline C23: 0, Tricosylic & 0.00 & \\
\hline C20: 5, Eicosapentaenoic & & & 0.00 \\
\hline C24: 1, Nervoic & 0.00 & 0.00 \\
\hline
\end{tabular}

Dry matter intake and digestion 
The basal diet (concentrate + grass) contained $2.73 \%$ lipids. Addition of $\mathrm{CO}$ to the concentrate at levels at 4,8 and $12 \%$ oil resulted in a total daily CO intake of $0,250,502$, and $752 \mathrm{~g}$, corresponding to $0,1.9,3.8$ and $5.3 \% \mathrm{CO}$, respectively, of the total diet (concentrate + grass) consumed during the experiment for each of the treatments (Table 2).

Table 2

Contribution of oil and total fat in the diet of cows fed Brachiaria sp and supplemented with canola oil.

\begin{tabular}{|c|c|c|c|c|c|c|c|}
\hline \multirow[t]{2}{*}{ Items } & \multicolumn{4}{|c|}{ Canola oil g/kg SBW ${ }^{1}$} & \multirow[t]{2}{*}{ SEM $^{2}$} & \multicolumn{2}{|c|}{ P-value ${ }^{3}$} \\
\hline & 0.00 & 0.40 & 0.80 & 1.20 & & $\mathbf{L}$ & Q \\
\hline Canola oil g/kg DMI & 0.0 & 19.1 & 38.8 & 54.1 & 11.8 & $<0.01$ & 0.32 \\
\hline \multicolumn{8}{|l|}{ Oil intake, $g / c o w / d$} \\
\hline Canola oil & 0.0 & 250 & 502 & 752 & 163.46 & $<0.01$ & 0.99 \\
\hline Grass & 146 & 170 & 157 & 175 & 0.54 & 0.62 & 0.47 \\
\hline Concentrate & 189 & 189 & 189 & 189 & 0.03 & 0.99 & 0.99 \\
\hline Total Fat & 335 & 609 & 847 & 1117 & 163.23 & $<0.01$ & 0.94 \\
\hline \multicolumn{8}{|c|}{ Contribution of total fat, \% } \\
\hline Canola oil & 0.0 & 41.1 & 59.2 & 67.4 & 15.02 & $<0.01$ & $<0.01$ \\
\hline Grass & 43.6 & 27.9 & 18.5 & 15.7 & 4.31 & $<0.01$ & $<0.01$ \\
\hline Concentrate & 56.4 & 31.0 & 22.3 & 16.9 & 3.56 & $<0.01$ & $<0.01$ \\
\hline \multicolumn{8}{|c|}{ Fat contribution to the diet, \% } \\
\hline Canola oil & 0.00 & 1.84 & 3.80 & 5.26 & 1.18 & $<0.01$ & 0.32 \\
\hline Grass & 1.19 & 1.25 & 1.18 & 1.22 & 0.10 & 0.02 & 0.87 \\
\hline Concentrate & 1.54 & 1.39 & 1.43 & 1.32 & 0.06 & 0.02 & 0.86 \\
\hline Total fat & 2.73 & 4.49 & 6.41 & 7.80 & 1.03 & $<0.01$ & 0.64 \\
\hline
\end{tabular}

The effects of the treatments on feed intake and digestion are shown in Table 3. An increment in CO intake from 0 to $1.20 \mathrm{~g} / \mathrm{kg}$ SBW increased (linear effect, $P<0.05)$ DM (16.6\%), organic matter (OM, $18.0 \%$ ) and gross energy intakes (26.3\%). While no change in $\mathrm{OM}$ and $\mathrm{CP}$ digestion was observed, the addition of CO caused a linear decrease $(P<0.05)$ of NDF at 2.5, 15.4 and $26.5 \%$ for levels $0.0,0.40,0.80$ and $1.20 \mathrm{~g} \mathrm{CO} / \mathrm{kg} \mathrm{SBW}$, respectively. Furthermore, the digestible energy (Mcal $/ \mathrm{kg})$ of the diets increased linearly $(P<0.01)$ by up to $7.1 \%$. 
Table 3

Effect of canola oil supplementation on dry matter intake, fecal excretion, and digestibility

\begin{tabular}{|c|c|c|c|c|c|c|c|}
\hline \multirow[t]{2}{*}{ Items } & \multicolumn{4}{|c|}{ Canola oil g/kg SBW ${ }^{1}$} & \multirow[t]{2}{*}{ SEM $^{2}$} & \multicolumn{2}{|c|}{ P-value ${ }^{3}$} \\
\hline & 0.00 & 0.40 & 0.80 & 1.20 & & L & Q \\
\hline \multicolumn{8}{|l|}{ alntake, $g / d$} \\
\hline Concentrate & 5787 & 5784 & 5785 & 5788 & 0.93 & 0.56 & 0.07 \\
\hline Canola oil & 0 & 250 & 502 & 752 & 163 & $<0.01$ & 0.99 \\
\hline Brachiaria sp & 6480 & 7519 & 6927 & 7758 & 289 & 0.11 & 0.80 \\
\hline DM & 12267 & 13557 & 13219 & 14306 & 423 & 0.02 & 0.81 \\
\hline $\mathrm{OM}$ & 10356 & 11541 & 11251 & 12221 & 387 & $<0.01$ & 0.77 \\
\hline NDF & 7852 & 7689 & 5994 & 6331 & 470 & 0.21 & 0.81 \\
\hline ADF & 3565 & 3980 & 3745 & 4156 & 130 & 0.11 & 0.99 \\
\hline $\mathrm{CP}$ & 1428 & 1495 & 1456 & 1511 & 19 & 0.11 & 0.82 \\
\hline GE, Mcal/d & 45.3 & 51.5 & 51.7 & 57.2 & 2.43 & $<0.01$ & 0.79 \\
\hline \multicolumn{8}{|c|}{ Fecal Excretion, g/d } \\
\hline DM & 4907 & 5423 & 5288 & 5722 & 169 & 0.02 & 0.81 \\
\hline $\mathrm{OM}$ & 3406 & 3445 & 3512 & 3627 & 48.4 & $<0.01$ & 0.13 \\
\hline NDF & 2553 & 2760 & 2550 & 3017 & 111 & 0.08 & 0.34 \\
\hline ADF & 1890 & 1991 & 1861 & 2149 & 65.0 & 0.22 & 0.41 \\
\hline CP & 424 & 470 & 447 & 482 & 12.8 & 0.17 & 0.82 \\
\hline GE, Mcal/d & 16.5 & 18.6 & 19.2 & 20.9 & 0.91 & $<0.01$ & 0.78 \\
\hline \multicolumn{8}{|l|}{ Digestibility, \% } \\
\hline $\mathrm{OM}$ & 66.9 & 69.3 & 68.0 & 69.2 & 0.57 & 0.28 & 0.57 \\
\hline NDF & 65.6 & 64.0 & 55.5 & 48.3 & 4.02 & 0.05 & 0.62 \\
\hline ADF & 46.2 & 49.1 & 50.6 & 45.2 & 1.25 & 0.94 & 0.28 \\
\hline CP & 70.3 & 68.6 & 69.5 & 68.5 & 0.42 & 0.34 & 0.74 \\
\hline DE & 63.5 & 63.7 & 62.8 & 63.0 & 0.21 & 0.52 & 0.96 \\
\hline DE, Mcal/d & 28.8 & 32.5 & 32.9 & 36.3 & 1.53 & $<0.01$ & 0.86 \\
\hline DE, Mcal $/ \mathrm{kg}$ & 2.34 & 2.42 & 2.46 & 2.52 & 0.04 & $<0.01$ & 0.79 \\
\hline
\end{tabular}




\begin{tabular}{|c|c|c|c|c|c|c|c|}
\hline \multirow[t]{2}{*}{ Items } & \multicolumn{4}{|c|}{ Canola oil g/kg SBW ${ }^{1}$} & \multirow[t]{2}{*}{ SEM $^{2}$} & \multicolumn{2}{|c|}{ P-value ${ }^{3}$} \\
\hline & 0.00 & 0.40 & 0.80 & 1.20 & & $\mathbf{L}$ & $\mathbf{Q}$ \\
\hline \multicolumn{8}{|c|}{$\begin{array}{l}{ }^{1} \text { SBW, shrunk body weight, BW } \times 0.96 \text { (NASEM, 2016); }{ }^{2} \mathrm{SEM} \text {, standard error means; }{ }^{3} \mathrm{P} \text {-value linear } \\
\text { and quadratic; DM, Dry Matter; OM, Organic Matter; NDF, Neutral Detergent Fiber; ADF, Acid Detergent } \\
\text { Fiber; CP, Nitrogen; GE, Gross Energy; DE, Digestible Energy; Mcal, Megacalories; }{ }^{\text {antake, was }} \\
\text { estimated based on fecal output (using } \mathrm{Cr}_{2} \mathrm{O}_{3} \text { as marker). }\end{array}$} \\
\hline
\end{tabular}

\section{Ruminal fermentation}

The effects of $\mathrm{CO}$ supplementation on $\mathrm{NH}_{3}-\mathrm{N}, \mathrm{pH}$, protozoa and VFA are shown in Table 4. The $\mathrm{N}-\mathrm{NH}_{3}$ and $\mathrm{pH}$ showed values between 25.53 and $34.37 \mathrm{mg} / \mathrm{dL}$ and 6.47 and 6.50 , respectively, and were not affected $(P>0.05)$ by $C O$ supplementation. The total ruminal protozoa population decreased $(29.7,69.5$ and $88.6 \%$; linear effect $P<0.01)$ with the addition of $\mathrm{CO}$ at the different levels $(0.4,0.8$ and $1.2 \mathrm{~g} / \mathrm{kg}$ SBW). This decrease was reflected by the Entodinidae (31.4, 68.8 and $88.8 \%$, respectively) and Holotrichidae $(11.2,77.5$ and $86.4 \%)$ populations. 
Table 4

Effect of canola-oil supplementation on ammoniacal nitrogen, $\mathrm{pH}$, protozoa, volatile fatty acids, and methane.

\begin{tabular}{|c|c|c|c|c|c|c|c|}
\hline \multirow[t]{2}{*}{ Items } & \multicolumn{4}{|c|}{ Canola oil g/kg SBW¹ } & \multirow[t]{2}{*}{ SEM $^{2}$} & \multicolumn{2}{|c|}{ P-value ${ }^{3}$} \\
\hline & 0.00 & 0.40 & 0.80 & 1.20 & & $\mathbf{L}$ & $\mathbf{Q}$ \\
\hline $\mathrm{NH}_{3}-\mathrm{N}, m g / d L$ & 25.5 & 26.7 & 33.0 & 34.4 & 2.23 & 0.27 & 0.99 \\
\hline $\mathrm{pH}$ & 6.49 & 6.50 & 6.47 & 6.48 & 0.006 & 0.783 & 0.986 \\
\hline \multicolumn{8}{|c|}{ Protozoa, $\times 10^{4} \mathrm{cel} / \mathrm{s} / \mathrm{mL}$} \\
\hline Entodinidae & 1844.6 & 1265.4 & 575.2 & 206.9 & 364.048 & $<0.01$ & 0.048 \\
\hline Holotrichidae & 166.5 & 147.9 & 37.5 & 22.7 & 37.008 & $<0.01$ & 0.792 \\
\hline Total Protozoa & 2011.0 & 1413.3 & 612.7 & 229.6 & 399.867 & $<0.01$ & 0.052 \\
\hline \multicolumn{8}{|c|}{ Volatile fatty acids, molar\% } \\
\hline TVFA, mM & 77.45 & 74.52 & 74.25 & 70.67 & 1.388 & 0.183 & 0.924 \\
\hline Acetic & 60.08 & 58.45 & 57.59 & 55.47 & 0.960 & $<0.01$ & 0.728 \\
\hline Propionic & 19.13 & 20.9 & 22.64 & 23.84 & 1.028 & $<0.01$ & 0.498 \\
\hline Butyric & 11.82 & 11.68 & 10.81 & 11.1 & 0.239 & 0.758 & 0.361 \\
\hline Valeric & 3.32 & 3.33 & 3.44 & 3.42 & 0.031 & $<0.01$ & 0.384 \\
\hline Iso-butyric & 2.60 & 2.58 & 2.51 & 2.68 & 0.035 & 0.904 & 0.408 \\
\hline Iso-valeric & 2.10 & 2.07 & 2.01 & 2.14 & 0.027 & 0.056 & 0.790 \\
\hline$A: P$ & 3.18 & 2.84 & 2.59 & 2.38 & 0.172 & $<0.01$ & 0.470 \\
\hline \multicolumn{8}{|c|}{ Infrared methane emissions } \\
\hline MER, mg/min & 0.92 & 0.85 & 0.82 & 0.49 & 0.096 & 0.001 & 0.252 \\
\hline $\mathrm{CH}_{4}, \mathrm{~g} / \mathrm{d}$ & 304.8 & 300.9 & 299.1 & 280.1 & 5.512 & 0.001 & 0.252 \\
\hline $\mathrm{CH}_{4}, \mathrm{~g} / \mathrm{kg} \mathrm{DMl}$ & 25.03 & 22.75 & 23.26 & 20.30 & 0.976 & 0.001 & 0.652 \\
\hline $\mathrm{CH}_{4}, \mathrm{~g} / \mathrm{kg} \mathrm{GEl}$ & 10.70 & 9.42 & 9.47 & 8.10 & 0.529 & 0.001 & 0.882 \\
\hline$Y_{m}$ & 7.04 & 6.78 & 6.78 & 6.58 & 0.094 & 0.005 & 0.692 \\
\hline \multicolumn{8}{|c|}{$\begin{array}{l}{ }^{1} \mathrm{SBW} \text {, shrunk body weight, BW } \times 0.96(\mathrm{NASEM}, 2016) ;{ }^{2} \mathrm{SEM} \text {, standard error means; }{ }^{3} \mathrm{P} \text {-value linear } \\
\text { and quadratic; } \mathrm{NH}_{3}-\mathrm{N} \text {, ammonia nitrogen; TVFA, Total Volatile Fatty Acids; A:P, Acetic acid to } \\
\text { propionic acid ratio; MER, Methane Emission Rate; } \mathrm{CH}_{4} \text {, Methane; DMI, Dry Matter Intake; GEI, Gross } \\
\text { Energy Intake; } \mathrm{Y}_{\mathrm{m}} \text {, GE loss, \% GEI. }\end{array}$} \\
\hline
\end{tabular}


No differences were observed in total ruminal concentrations of VFA as well as butyric, iso-butyric and iso-valeric acids: 74.2, 11.4, 2.6 and $2.1 \mathrm{mM}$, respectively. Furthermore, acetic acid decreased linearly $(\mathrm{P}<$ $0.01)$ to $7.7 \%$, whereas propionic and valeric acids increased $(P<0.01)$ to 24.6 and $3.0 \%$, respectively, with $\mathrm{CO}$ supplementation compared to the control. Consequently, the acetate propionate ratio decreased by $10.7,18.6$ and $25.2 \%$ for the levels of $0.40,0.80$ and $1.20 \mathrm{~g} \mathrm{CO} / \mathrm{kg}$ SBW, respectively.

\section{Methane emissions}

The enteric emissions of $\mathrm{CH}_{4}$ are shown in Table 4. Compared with the diet without canola oil supplementation, the $\mathrm{CH}_{4}$ emission rate (MER) decreased linearly $(7.61,10.87$ and $46.74 \%, \mathrm{P}<0.05)$ as the $\mathrm{CO}$ level in the diet increased. For $\mathrm{CH}_{4}$ expressed in $\mathrm{g} / \mathrm{d}$, the observed decrease (linear effect, $\mathrm{P}<0.05$ ) was $1.29,1.87$ and $8.12 \%$, whereas for $\mathrm{CH}_{4}$ expressed as $\mathrm{g} / \mathrm{kg} \mathrm{DMI}$, the decrease (linear effect, $\mathrm{P}<0.01$ ) was $9.09,7.08$ and $18.91 \%$. For $\mathrm{CH}_{4}$ expressed in $\mathrm{g} / \mathrm{kg} \mathrm{GHG}$, the linear decrease $(\mathrm{P}<0.01)$ was 11.93 , 11.48 and $24.23 \%$ for $0.0,0.40,0.80$ and $1.20 \mathrm{~g} \mathrm{CO} / \mathrm{kg} \mathrm{SBW}$, respectively.

The estimated values of the loss of energy by the emission of $\mathrm{CH}_{4}\left(\mathrm{Y}_{\mathrm{m}}\right)$ were $7.04,6.78,6.78$ and $6.58 \%$, whereas those estimated using the methodology of the IPCC (2006) were 140.5, 160.8, 158.8 and 177.3 $\mathrm{g} / \mathrm{kg}$ of $\mathrm{CH}_{4}$ for the consumption levels of $0.40,0.80$ and $1.20 \mathrm{~g} \mathrm{CO} / \mathrm{kg} \mathrm{SBW}$, respectively.

\section{Discussion}

\section{Chemical composition}

The chemical composition of Brachiaria sp. agrees with that reported in previous studies considering a similar state of maturity (Avellaneda et al., 2008). The concentration of nutrients in the commercial concentrate closely conformed to that specified on the label provided by the food manufacturer. Similarly, the fatty acid profile of the canola oil used agrees with that reported by the AFOA (1988), confirming that canola oil is an important source of oleic FA $(70.32 \%$ C18:1).

\section{Intake and digestibility}

The inclusion of 4,8 and $12 \% \mathrm{CO}$ to the concentrate, plus the lipid content of the basal diet (concentrate + grass), corresponded to a total lipid concentration (DMB) of 2.7, 4.5, 6.4 and $7.8 \%$ in the final diet for the treatments with $0.0,0.40,0.80$ and $1.2 \mathrm{~g} \mathrm{CO} / \mathrm{kg} \mathrm{SBW}$, respectively. Generally, lipid supplementation above $7 \%$ DM may decrease intake due to an increase in circulating unsaturated FAs that cause activation of receptors in the hypothalamus satiety centre and a reduction in fibre digestibility, resulting in reduced DMI (Allen, 2000; Kumar, 2014). Several mechanisms may explain how dietary lipids interfere with ruminal fermentation. In this study, a decrease was observed in the digestibility of NDF, most likely because longchain FA present in the $\mathrm{CO}$ and those who escape biohydrogenation are potentially toxic for the bacteria responsible for fibre degradation (cellulolytic, gram + ) and for methanogens and protozoa (Desbois and Smith, 2010; Zeitz et al., 2013). Also, fats form a physical coating on the fibre, preventing microbial degradation, which has a negative effect on voluntary consumption (Jenkins, 1993). However, the effects 
of the addition of supplementary oils on the consumption and digestibility of fresh forages are inconsistent. Some studies involving oil supplementation with fresh forages indicate reductions in both feed intake and overall dietary digestibility (Pavan et al., 2007; Cosgrove et al., 2008), whereas other studies (King et al., 1990; Woodward et al., 2006) found no effect on food intake. On the contrary, Ueda et al. (2003) reported a higher digestibility and feed intake of a high-forage diet supplemented with $3 \%$ flaxseed oil. In grazing cows, supplementation reduces the consumption of grass due to a substitution effect but increases the total DMI (Vazquez and Smith, 2000). In the present study, a reduction in DMI was not observed; on the contrary, an increase in DMl and OMI occurred when increasing the CO inclusion level (Table 3). Thus, the low ruminal digestion of NDF can be explained more plausibly by an increase in the rate of fibre passage than by a direct reduction of oil. of the consumption of green pastures supplemented with oil has been previously investigated by Piñares-Patiño et al. (2016), who observed that steers grazing Lolium perenne increased their DMI $(P<0.05)$ when roseate $C O$ was added to the pasture. Similarly, Beauchemin et al. (2006) observed an increase in DMI and the intake of digestible energy when a diet based on barley silage supplemented with $3.8 \%$ sunflower oil; compared with other sources of fat, such as tallow or whole sunflower seed, sunflower oil had a minimal effect on fibre digestibility. These studies attribute that the increase in DMI of the forage can be explained by the possible increase in the rate of passage of the fibre fraction in forage rich in moisture and supplemented with moderate amounts of oil, considering that the lipid contribution of green pastures is low (Harfoot and Hazlewood, 1997), as observed in the present experiment (2.26\% lipids on average).

\section{Ruminal fermentation}

The addition of FA can have a toxic effect on rumen protozoa when offered in large quantities (Machmüller and Kreuzer, 1999). According to Gawad et al. (2015), this is mainly observed in protozoa of the family Holotrichidae. In the present study, the ratio of acetate/propionate decreased significantly with the addition of canola oil, which is consistent with the findings of Beauchemin and McGinn (2006). As mentioned above, unsaturated FA can change the ruminal microbiota, and the resulting changes may be the reason for changing the rumen fermentation towards propionate (Guyader et al., 2015). Most likely, this occurs because gram negative (propionate-producing) bacteria are not specifically inhibited by FA (Van Nevel and Demeyer, 1988); thus, the reduction in $\mathrm{CH}_{4}$ emissions observed when FAs are included in the ruminant diet mainly results from a shift towards propionate production.

\section{Methane emissions}

Enteric methane emission, expressed as $\mathrm{g} \mathrm{CH}_{4} / \mathrm{kg} \mathrm{DMl}$, for the cows that consumed the pasture without oil supplementation in this study was $19.3 \mathrm{~g} \mathrm{CH}_{4} / \mathrm{kg} \mathrm{DM}$ (range 15.8-22.4 $\mathrm{g} \mathrm{CH}_{4} / \mathrm{kg} \mathrm{DMI}$ ), which was similar to the values reported by Kennedy and Charmley (2012) for cattle consuming pastures and tropical legumes $\left(19.6 \mathrm{~g} / \mathrm{kg} \mathrm{DMI}\right.$ ) and the $20 \mathrm{~g} \mathrm{CH}_{4} / \mathrm{kg}$ DMI recorded by Beauchemin (2006) for a base diet of $75 \%$ barley silage and $19 \%$ steam-rolled barley. However, it was lower than the $28 \mathrm{~g} \mathrm{of} \mathrm{CH}_{4} / \mathrm{kg} \mathrm{DMI}$ reported for cattle grazing leucaena (McGinn et al., 2011). Variations in the values of methane emissions among studies are mainly due to the technique used to measure methane and the chemical composition of the forage consumed. Beauchemin et al. (2007) found that sunflower oil, which is rich in linoleic acid 
(C18:2), was effective in reducing the emissions of $\mathrm{CH}_{4}$ by $14 \%$ (177.4 vs. $152.7 \mathrm{~g} /$ day and $20 \mathrm{vs}$.

$17.7 \mathrm{~g} / \mathrm{kg} \mathrm{DMI}$ ). The authors concluded that adding 3.3\% lipids to forage diets in the form of unsaturated FA limits $\mathrm{CH}_{4}$ emissions and could have substantial effects on $\mathrm{CH}_{4}$ inventories. Various studies have suggested that, through different mechanisms of action, lipids reduce the $\mathrm{CH}_{4}$ production in the rumen (Dohme et al., 2001; Machmüller et al., 2001; Bayat et al., 2018; Muñoz et al., 2019; Nogueira et al., 2020). Reductions in the emission of methane $\left(\mathrm{CH}_{4} / \mathrm{kg} \mathrm{DM} / \mathrm{d}\right)$ of $11.5 \%$ have been reported for $3.4 \%$ sunflower oil supplementation fed to cattle consuming diets based on barley silage (Beauchemin et al., 2006). Moate et al. (2011) report that the addition of fat in diets of lactating cows (60:40 ratio of forage: concentrate) containing 51, 52 and $65 \mathrm{~g}$ fat $/ \mathrm{kg}$ DM decreases the emissions of $\mathrm{CH}_{4}(\mathrm{~g} /$ day) by 7.6, 4.5 and $10.2 \%$, respectively, compared to a control diet. In another study, Moate et al. (2014) recorded a reduction in emissions of $\mathrm{CH}_{4}$ at about $20 \%$ with an add grape marc (high fat source and tannins) diet for lactating cows. The same research group (Moate et al., 2016) performed a meta-analysis of 362 individual measurements in lactating cows from 12 different experiments and estimated that for a typical diet containing $30 \mathrm{~g}$ of lipids $/ \mathrm{kg} \mathrm{DMI}$, for each $1 \%$ increase in the concentration of fat in the diet, the methane emissions will decrease by approximately 3.5\%. A study by Woodward et al. (2006), carried out with lactating dairy cows fed pasture forage dominated by perennial ryegrass $(13.5-15.0 \mathrm{~kg} \mathrm{DMl} / \mathrm{d})$ supplemented with $500 \mathrm{~g}$ of fish oil, reported a reduction (compared to the control) in the $\mathrm{CH}_{4}$ yield of $27 \%$. Martin et al. (2010), in a metanalysis with 67 in-vivo diets for sheep, beef and dairy cattle, estimated an average $3.8 \%$ decrease in enteric $\mathrm{CH}_{4}(\mathrm{~g} / \mathrm{kg} \mathrm{DMI})$ with each $1 \%$ added fat, which is consistent with the $3.6 \%$ decrease per $1 \%$ oil added observed in the present study.

The estimated values of $Y_{m}$ decreased $(P<0.05)$ by up to $6.5 \%$ with the addition of up to $1.20 \mathrm{~g} \mathrm{CO} / \mathrm{kg}$ $\mathrm{PMr}$, taking into account that the formula used in the experiment (Sauvant and Giger-Reverdin, 2009) considers the proportion of the concentrate; for all treatments, it was $47 \%$, and the decrease in energy loss by the emission of $\mathrm{CH}_{4}$ is attributed to the addition of $\mathrm{CO}$. Gerber et al. (2013) consider that concentrates can influence the decrease of enteric $\mathrm{CH}_{4}$ from $35-40 \%$ of inclusion; at inclusion levels $>40 \%$, there could be a decrease in fibre digestibility.

Regarding the estimation of $\mathrm{CH}_{4}$ emissions with the IPCC methodology (2006), an increase in methane emissions of $14.4,13.0$ and $26.2 \% \mathrm{~g} / \mathrm{d}$ was observed for treatments with $0.0,0.40,0.80$ and $1.2 \mathrm{~g} \mathrm{CO} / \mathrm{kg}$ SBW, respectively, which is explained by the increase in the GE of the diets. Escobar-Bahamondes et al. (2017) mention that the use of a constant GE value results in the equation being only sensitive to changes in $\mathrm{DMl}$ and not to changes in the composition of diets, digestibility and rumen fermentation. Therefore, using the IPCC model, changes in $\mathrm{CH}_{4}$ are strictly due to changes in DMI, which is a limitation of the IPCC 2006 model; although in the 2019 refinement, the DMI estimates are modified in some categories, the estimate of energy is not modified. We therefore conclude that canola oil supplemented at $1.2 \mathrm{~g} \mathrm{CO} / \mathrm{kg} \mathrm{SBW}(5.4 \%)$ and a contribution of up to $7 \%$ total fat in the diet (DMB) of cows grazing tropical fodder, supplemented with a fixed amount of concentrate, can increase the total energy intake and efficiency of rumen fermentation, thereby reducing the emission of enteric methane by up to $18.9 \%$. 
Although CO supplementation decreased the total digestibility of NDF by $26 \%$, the DE value (Mcal $/ \mathrm{kg})$ of the diet increased by $7.1 \%$

\section{Declarations}

\section{Acknowledgements}

The first author thanks the National Council for Science and Technology (CONACYT, Mexico) for granting a scholarship to carry out the PhD work at the Department of Animal Nutrition and Biochemistry FMVZUNAM. We thank the technicians for their significant contributions, A. García-Pérez (laboratory analysis) and J.M. Talamantes-Gómez (fatty acid analysis and chromatography).

Funding This project was partially supported by Grant PAPIIT, DGAPA UNAM (IT202120).

Conflict of interest The authors declare no competing interests.

Ethicals approval The protocols used in this study were reviewed and approved by the Universidad Nacional Autónoma de México, Institutional Committee for the Care and Use of Experimental Animals, according to official animal care normativity (NOM-062-Z0O-1999) (Diario Oficial de la Federación, 2001).

Consent to participate All authors have consented to participate.

Consent for publication All the authors consent to publish the manuscript.

Data availability The data that support the findings of this study are available from the corresponding author, upon reasonable request.

Code availability Not applicable

Author contribution L.C., C.C.M.M. and A.P. conceived and design research. J.N.A.N. and E.C.G., conducted experiments. L.C., J.N.A.N. E.C.G and J.H.H.H. analysed data. J.AN.A.N., L.C., A.P., F.A.C.P., J.H,H.M. and J.E.R.B. wrote the manuscript. All authors read and approved the manuscript.

\section{References}

1. American Fats and Oils Association - AFOA. 1988. Trading and Arbitration Rules. American Fats and Oils Association, Inc. New York.

2. Allen, M.S. 2000. Effects of diet on short-term regulation of feed intake by lactating dairy cattle. Journal of dairy science, 83 (7), 1598-1624.

3. Association of Official Analytical chemists - AOAC. 2019. Official Methods of Analysis. 21st ed (AOAC international, Urbana. USA).

4. Association of Official Analytical chemists - AOAC. 2015. Official methods of analysis. 19th ed (AOAC international, Urbana. USA). 
5. Audsley, E., \& Wilkinson, M. 2014. What is the potential for reducing national greenhouse gas emissions from crop and livestock production systems? Journal of Cleaner production, 73, 263-268.

6. Avellaneda Cevallos, J.; Cabezas Guerrero, F.; Quintana Zamora, G.; Luna Murillo, R.; Montañez Valdez, O.D.; Espinoza Guerra, I. \& Pinargote Mendoza, E. 2008. Agronomic behavior and chemical composition of three varieties of "Brachiaria" at different harvest ages. Science and technology (Quevedo), 1 (2), 87-94.

7. Bayat, A.R.; Tapio, I.; Vilkki, J.; Shingfield, K.J.; Leskinen, H. 2018. Plant oil supplements reduce methane emissions and improve milk fatty acid composition in dairy cows fed grass silage-based diets without affecting milk yield. Journal of dairy science, 101 (2), 1136-1151.

8. Beauchemin, K.A. 2015. Mitigation of enteric methane production through efficient feeding of dairy cows. Memories of the XVII Biennial Congress, Mexican Association of Specialists in Animal Nutrition. Puerto Vallarta, Jal. México.

9. Beauchemin, K.A.; McGinn, S.M. 2006. Methane emissions from beef cattle: Effects of fumaric acid, essential oil, and canola oil. Journal of Animal Science, 84 (6), 1489-1496.

10. Beauchemin, K.A.; McGinn, S.M.; Petit, H.V. 2007. Methane abatement strategies for cattle: Lipid supplementation of diets. Canadian Journal of Animal Science, 87 (3), 431-440.

11. Bonilla Cárdenas, J.A.; Lemus Flores, C. 2012. Emission of enteric methane by ruminants and its contribution to global warming and climate change: Review. Mexican Journal of Livestock Sciences, $3(2), 215-246$.

12. Castro-Montoya, J.; Peiren, N.; Cone, J.W.; Zweifel, B.; Fievez, V.; De Campeneere, S. 2015. In vivo and in vitro effects of a blend of essential oils on rumen methane mitigation. Livestock Science, 180, 134142.

13. Cochran W.G.; Cox G.M. 1957. Experimental designs. 2nd ed. Wiley Classics Library. John Wiley \& Sons. New York, USA.

14. Conway, E.J.; O'malley, E. 1942. Microdiffusion methods. Ammonia and urea using buffered absorbents (revised methods for ranges greater than $10 \mu \mathrm{g}$. N). Biochemical Journal, 36 (7-9), 655.

15. Cosgrove, G.P.; Waghorn, G.C.; Anderson, C.B.; Peters, J.S.; Smith, A.: Molano, G.; Deighton, M. 2008. The effect of oils fed to sheep on methane production and digestion of ryegrass pasture. Australian Journal of Experimental Agriculture, 48 (2), 189-192.

16. Desbois, A.P.; Smith, V.J. 2010. Antibacterial free fatty acids: activities, mechanisms of action and biotechnological potential. Applied microbiology and biotechnology, 85 (6), 1629-1642.

17. Dohme, F.; Machmüller, A.; Wasserfallen, A.; Kreuzer, M. 2001. Ruminal methanogenesis as influenced by individual fatty acids supplemented to complete ruminant diets. Letters in Applied Microbiology, $32(1), 47-51$.

18. Escobar-Bahamondes, P.; Oba, M.; Kröbel, R., McAllister, T.A.; MacDonald, D.; Beauchemin, K.A. 2017. Estimating enteric methane production for beef cattle using empirical prediction models compared with IPCC Tier 2 methodology. Canadian Journal of Animal Science, 97 (4), 599-612. 
19. García, E. 2004. Modificaciones al sistema de clasificación climática de Köppen. $5^{\text {ta }}$ ed. Universidad Nacional Autónoma de México. Instituto de geografía. México. ISBN 970-32-1010-4.

20. Garnsworthy, P.C.; Craigon, J.; Hernandez-Medrano, J.H.; Saunders, N. 2012. On-farm methane measurements during milking correlate with total methane production by individual dairy cows. Journal of dairy science, 95 (6), 3166-3180.

21. Gawad, R.M.A.; Kattab, H.M.; Strabel, M.; El-Nor, S.A.; Cieslak, A.; Zmora, P.; ... Kolif, S.M. 2015. Effect of different levels from linseed oil and linseed oil beads on rumen fermentation and microbial parameters using gas production system and rumen simulation technique. Asian Journal of Animal and Veterinary Advances, 10(3), 97-118.

22. Gerber, P.J.; Henderson, B.; Makkar, H.P. 2013. Mitigation of greenhouse gas emissions in livestock production: a review of technical options for non- $\mathrm{CO}_{2}$ emissions (No. 177). Food and Agriculture Organization of the United Nations (FAO).

23. Grainger, C.; Beauchemin, K.A. 2011. Can enteric methane emissions from ruminants be lowered without lowering their production? Animal feed science and technology, 166, 308-320.

24. Guyader, J.; Eugène, M.; Meunier, B.; Doreau, M.; Morgavi, D.P.; Silberberg, M.; ... Martin, C. 2015. Additive methane-mitigating effect between linseed oil and nitrate fed to cattle. Journal of Animal Science, 93 (7), 3564-3577.

25. Harfoot, C.G.; Hazlewood, G.P.; Hobson, P.N.; Stewart, C.S. 1997. The rumen microbial ecosystem. eds. Hobson PN and Stewart CS, Chapman \& Hall, London, 382-426.

26. Hristov, A.N.; Oh, J.; Firkins, J.L.; Dijkstra, J.; Kebreab, E.; Waghorn, G.; ... Gerber, P.J. 2013. Special topics, Mitigation of methane and nitrous oxide emissions from animal operations: I. A review of enteric methane mitigation options. Journal of animal science, 91 (11), 5045-5069.

27. Hristov, A.N.; Oh, J.; Giallongo, F.; Frederick, T.W.; Harper, M.T.; Weeks, H.L.; Branco A.F.; Moate P.J.; Deighton M.H.; Williams R.O.; Kindermann, M.; Duval, S. 2015. An inhibitor persistently decreased enteric methane emission from dairy cows with no negative effect on milk production. Proceedings of the National Academy of Sciences, 112 (34), 10663-10668.

28. Intergovernmental Panel on Climate Change - IPCC. (2006). Emissions from livestock and manure management. 2006 IPCC guidelines for national greenhouse gas inventories.

29. Jenkins, T.C.; Palmquist, D.L. 1984. Effect of fatty acids or calcium soaps on rumen and total nutrient digestibility of dairy rations. Journal of Dairy Science, 67 (5), 978-986.

30. Jenkins, T.C. 1993. Lipid metabolism in the rumen. Journal of dairy science, 76 (12), 3851-3863.

31. Johnson K.A.; Johnson D.E. 1995. Methane emissions from cattle. Journal of Animal Science, 73, 2483-2492.

32. Kennedy, P.M.; Charmley, E. 2012. Methane yields from Brahman cattle fed tropical grasses and legumes. Animal Production Science, 52 (4), 225-239.

33. King, K.R.; Stockdale, C.R.; Trigg, T.E. 1990. Influence of high energy supplements containing fatty acids on the productivity of pasture-fed dairy cows. Australian Journal of Experimental Agriculture, 
$30(1), 11-16$.

34. Knapp, J.R.; Laur, G.L.; Vadas, P.A.; Weiss, W.P.; Tricarico, J.M. 2014. Invited review: Enteric methane in dairy cattle production: Quantifying the opportunities and impact of reducing emissions. Journal of dairy science, $97(6), 3231-3261$.

35. Kumar, S.; Choudhury, P.K.; Carro, M.D.; Griffith, G.W.; Dagar, S.S.; Puniya, M.; ... Sirohi, S.K. 2014. New aspects and strategies for methane mitigation from ruminants. Applied Microbiology and Biotechnology, $98(1), 31-44$.

36. Machmüller, A.; Kreuzer, M.C.J.A.S. 1999. Methane suppression by coconut oil and associated effects on nutrient and energy balance in sheep. Canadian Journal of Animal Science, 79 (1), 65-72.

37. Machmüller, A.; Dohme, F.; Soliva, C.R.; Wanner, M.; Kreuzer, M. 2001. Diet composition affects the level of ruminal methane suppression by medium-chain fatty acids. Australian Journal of Agricultural Research, 52 (7), 713-722.

38. Martin, C.; Ferlay, A.; Mosoni, P.; Rochette, Y.; Chilliard, Y.; Doreau, M. 2016. Increasing linseed supply in dairy cow diets based on hay or corn silage: Effect on enteric methane emission, rumen microbial fermentation, and digestion. Journal of Dairy Science, 99 (5), 3445-3456.

39. Martin, C.; Morgavi, D.P.; Doreau, M. 2010. Methane mitigation in ruminants: from microbe to the farm scale. Animal, 4 (3), 351-365.

40. Mata e Silva, B.M.; Lopes, F.C.F.; Pereira, L.G.R.; Tomich, T.R.; Morenz, M.J.F.; Martins, C.E.; ... Chaves, A.V. 2017. Effect of sunflower oil supplementation on methane emissions of dairy cows grazing Urochloa brizantha cv. marandu1. Animal production science, 57(7), 1431-1436.

41. McGeough, E.J.; O'kiely, P.; Hart, K.J.; Moloney, A.P.; Boland, T.M.; Kenny, D.A. 2010. Methane emissions, feed intake, performance, digestibility, and rumen fermentation of finishing beef cattle offered whole-crop wheat silages differing in grain content. Journal of Animal Science, 88 (8), 27032716.

42. McGinn, S.M.; Turner, D.; Tomkins, N.; Charmley, E.; Bishop-Hurley, G.; Chen, D. 2011. Methane emissions from grazing cattle using point-source dispersion. Journal of environmental Quality, 40 (1), 22-27.

43. Moate, P.J.; Deighton, M.H.; Williams, S.R.O.; Pryce, J.E.; Hayes, B.J.; Jacobs, J.L.; ... Wales, W.J. 2016. Reducing the carbon footprint of Australian milk production by mitigation of enteric methane emissions. Animal Production Science, $56(7), 1017-1034$.

44. Moate, P.J.; Williams, S.R.O.; Grainger, C.; Hannah, M.C.; Ponnampalam, E.N.; Eckard, R.J. 2011. Influence of cold-pressed canola, brewers grains and hominy meal as dietary supplements suitable for reducing enteric methane emissions from lactating dairy cows. Animal Feed Science and Technology, 166, 254-264.

45. Moate, P.J.; Williams, S.R.O.; Torok, V.A.; Hannah, M.C.; Ribaux, B.E.; Tavendale, M.H.; ... Wales, W.J. 2014. Grape marc reduces methane emissions when fed to dairy cows. Journal of Dairy Science, 97 (8), 5073-5087. 
46. Muñoz, C.; Sánchez, R.; Peralta, A.M.T.; Espíndola, S.; Yan, T.; Morales, R.; Ungerfeld, E.M. 2019. Effects of feeding unprocessed oilseeds on methane emission, nitrogen utilization efficiency and milk fatty acid profile of lactating dairy cows. Animal feed science and technology, 249, 18-30.

47. National Academies of Science, Enginnering, and Medicine - NASEM. 2016. Nutrient Requeriments of Beef Cattle, Eight Revised Edition, Washington, D.CX. The National Academics Press.

48. Nogueira, R.G.S.; Perna Junior, F.; Pereira, A.S.C.; Cassiano, E.C.O.; Carvalho, R.F.; Rodrigues, P.H.M. 2020. Methane mitigation and ruminal fermentation changes in cows fed cottonseed and vitamin $E$. Scientia Agricola, $77(6)$.

49. Orsavova, J.; Misurcova, L.; Ambrozova, J.V.; Vicha, R.; Mlcek, J. 2015. Fatty acids composition of vegetable oils and its contribution to dietary energy intake and dependence of cardiovascular mortality on dietary intake of fatty acids. International journal of molecular sciences, 16 (6), 1287112890.

50. Pavan, E.; Duckett, S.K.; Andrae, J.G. 2007. Corn oil supplementation to steers grazing endophyte-free tall fescue. I. Effects on in vivo digestibility, performance, and carcass traits. Journal of animal science, $85(5), 1330-1339$.

51. Piñares-Patiño, C.S.; Franco, F.E.; Molano, G.; Kjestrup, H.; Sandoval, E.; MacLean, S.; Laubach, J. 2016. Feed intake and methane emissions from cattle grazing pasture sprayed with canola oil. Livestock Science, 184, 7-12.

52. Sauvant, D.; Giger-Reverdin, S. 2009. Modélisation des interactions digestives et de la production de méthane chez les ruminants. INRA Prod. Anim. 22: 375-384.

53. Schneider, B.H.; Flatt, W.P. 1975. The evaluation of feeds through digestibility experiments. University of Georgia Press.

54. Ueda, K.; Ferlay, A.; Chabrot, J.; Loor, J.J.; Chilliard, Y.; Doreau, M. 2003. Effect of linseed oil supplementation on ruminal digestion in dairy cows fed diets with different forage: concentrate ratios. Journal of Dairy Science, 86 (12), 3999-4007.

55. Van Nevel, C.J.; Demeyer, D.I.; Hobson, P.N. 1988. The rumen microbial ecosystem. Manipulation of Rumen Fermentation, 387-444.

56. Van Soest, P.; Robertson, J.; Lewis, B. 1991. Methods for dietary fiber, neutral detergent fiber and nonstarch polysaccharides in relation to animal nutrition. Journal Dairy Science. 74: 3583-3597.

57. Vazquez O.P., Smith T.R. Factors affecting pasture intake and total dry matter intake in grazing dairy cows. Journal of Dairy Science, 83 (10), 2301-2309.

58. Williams, C.H.; David, D.J; lismaa, O. 1962. The determination of chromic oxide in faeces samples by atomic absorption spectrophotometry. The Journal of Agricultural Science, 59 (3), 381-385.

59. Woodward, S.L. 2006. Supplementing dairy cows with oils to improve performance and reduce methane-does it work? In Proceedings-New Zealand Society of Animal Production (Vol. 66, p. 176). New Zealand Society of Animal Production; 1999.

60. Wu, D.; Xu, L.; Tang, S.; Guan, L.; He, Z.; Guan, Y.; ... Wang, M. 2016. Influence of oleic acid on rumen fermentation and fatty acid formation in vitro. PloS one, 11 (6), e0156835. 
61. Zeitz, J.O.; Kreuzer, M.; Soliva, C.R. 2013. In vitro methane formation and carbohydrate fermentation by rumen microbes as influenced by selected rumen ciliate species. European journal of protistology, 49 (3), 389-399.

62. Zinn, R.A.; Jorquera, A.P. 2007. Feed value of supplemental fats used in feedlot cattle diets. Veterinary Clinics of North America: Food Animal Practice, 23 (2), 247-268. 